\title{
ISOLATION, CHARACTERIZATION, AND IDENTIFICATION OF PROTEOLYTIC BACTERIA TO IMPROVE PROTEIN DIGESTIBILITY OF FISH FEED INGREDIENTS
}

\author{
Mulyasari\#, Mas Tri Djoko Sunarno, and Lusi Herawati Suryaningrum \\ Research Institute for Freshwater Aquaculture and Fisheries Extension \\ Jl. Sempur No. 1, Bogor, West Java 16129
}

(Received 29 January 2018; Final revised 18 July 2018; Accepted 18 July 2018)

\begin{abstract}
Protease is one of the potential enzymes used to improve the quality of local raw materials as fish feedstuff. The aim of this research was to find high protease activity-bacteria isolates in improving protein digestibility of fish feedstuff. Isolation was conducted on various growth substrates such as water and sediment of hot springs, mangrove sediment, and shrimp head waste. The parameters used in the selection and characterization of potential proteolytic bacteria were qualitative and quantitative tests of proteolytic activity. Microbes that have the highest enzyme activity were then selected and characterized based on their growth curve, production time of protease, and determination of optimum condition (temperature and $\mathrm{pH}$ ) of protease activity. The result showed that there are only 18 isolates from 44 isolates positively had protease activity (qualitatively). Three isolates with the highest activity (RGL1.1, PL1.1, and PL1.2) qualitatively and quantitatively were then selected to be tested for their pathogenecity on tilapia. The results showed that only RGL1.1 was not pathogenic and therefore, potentially used as a protease producer candidate. The characterization of RGL1.1 isolates showed that the exponential phase of RGL1.1 was thirty-sixth hour in line with the optimum activity of enzyme production. The optimum $\mathrm{pH}$ and temperature of RGL1.1 isolate were 6 and $50^{\circ} \mathrm{C}$, respectively. RGL1.1 isolate is a Gram-positive rod-shaped bacteria that has $99.53 \%$ of resemblance to Bacillus cereus.
\end{abstract}

\section{KEYWORDS: proteolytic bacteria; isolation; characterization; identification}

\section{INTRODUCTION}

Protease is one of the important enzymes for industrial and agricultural biotechnology applications. This enzyme has been used extensively in animal feed industry and contributed to $65 \%$ of the total sales of enzymes in the world (Badriyah \& Ardyati, 2013). Protease (E.C.3.4) is a hydrolase class enzyme that plays a role in the peptide-binding reaction to protein molecules. This enzyme catalyzes the hydrolysis reaction, a reaction involving the water element to the specific bond of the substrate (Kurniawan, 2015).

Similar to the animal feed industry, protease can potentially be used to improve the quality of fish feed ingredients in aquaculture. This is because the proportion of indigestible protein in the average raw material is still relatively high. For example, the undigested protein in sorghum, wheat, corn, soybean,

\footnotetext{
\# Correspondence: Research Institute for Freshwater Aquaculture and Fisheries Extension

Jl. Sempur No. 1, Bogor, West Java 16129, Indonesia Phone: + 622518313200

E-mail: mulyasari_bogor@yahoo.co.id
}

and wheat bran or rice bran are $22 \% 23 \% 27.3 \% 20.7 \%$ and $28.8 \%$ respectively (Marlina, 2014). In addition, some anti-nutritional factors in the protein of feed ingredients such as lectin and trypsin inhibitors can trigger damages to the absorption surface, due to the imperfection of the digestive process. The addition of proteases can help neutralize the negative effects of these protein factors and also break down hard-to-digest proteins into simpler, more readily absorbed molecules. Protease can also be used to improve the quality of several potential feed ingredients such as blood meal, poultry meal, and shrimp head or shrimp skin meal.

Protease can be produced by microorganisms such as bacteria. The use of microorganisms as sources of enzymes has several advantages over enzymes iso lated from plants or animals. Microorganism cells are relatively more easily to be grown, have relatively faster growth rates, can easily be produced in large quantities when needed, and are cost effective. The production of microorganism cell is not dependent on seasonal changes, need shorter production time (Rahman \& Indarto, 2013). Such advantages mean that 
it is important to explore, isolate, characterize, and identify potential protease-producing bacteria in order to improve protein digestibility of fish feed ingredients. Protease-producing bacteria can be isolated from various growth substrates such as hot springs, mangroves, shrimp wastes, and others. The aim of this study was to obtain bacterial isolates that have high protease activity and potentially be used to improve protein digestibility of fish feedstuff.

\section{MATERIALS AND METHODS}

The analysis was conducted at the Nutrition and Feed Technology Laboratory, Research Center and Development of Freshwater Aquaculture. Sampling were conducted in Saguling, Cianjur; Ciseeng, Bogor; White crater; and Rengganis crater in Bandung; Eretan, Indramayu; Muara Angke, Jakarta from February to October 2016.

\section{Exploration and Isolation of Proteolytic Bacteria from Various Growth Substrates}

The first stage of this research was the exploration and isolation of microbes on various growth substrates such as hot spring water and sediment, mangrove sediment, and shrimp head. The samples were diluted gradually and $100 \mu \mathrm{L}$ of samples were collected and dripped onto a skimmed milk medium agar, flattened and incubated at $37^{\circ} \mathrm{C}$ for \pm 48 hours. Each colony was purified during the growing period. After 48 hours, the growing colony then was observed macroscopically to determine its shape, size, texture, and color.

\section{Selection and Characterization of Protease- Producing Bacteria from Various Growth Substrates}

The next stage of this research was the selection and characterization of proteolytic bacteria. Several tests were conducted in the selection of proteolytic bacteria including qualitative and quantitative tests of proteolytic activity as well as pathogenicity test. Isolate that has the highest enzyme activity and not pathogenic to fish was then selected as the candidate of proteolytic bacteria. After that, the isolate was characterized by its microbial growth curve, production time of protease enzyme, and protease enzyme activity optimum conditions (temperature and optimum $\mathrm{pH}$ ).

\section{Selection of proteolytic bacteria}

\section{Qualitative test of proteolytic activity}

Qualitative proteolytic test of the isolates was done by using skim milk agar (SMA) media. Each isolate was placed into a petri dish containing SMA media and then incubated for 24 hours at $37^{\circ} \mathrm{C}$. Proteolytic activity is indicated by the appearance of clear zones around the formed colonies. The calculation of proteolytic index is the ratio of total zone diameter extending from the center of the bacterial colonies. The proteolytic index is calculated as follows (Firliani et al., 2015):

where:

$$
\text { Proteolytic index }=\frac{(a-b)}{b}
$$

$\mathrm{a}=$ the diameter of the total zone

$\mathrm{b}=$ diameter of colony

\section{Quantitative proteolytic activity test}

$1 \mathrm{~mL}$ of the isolate was cultured in $9 \mathrm{~mL}$ Trypticase Soy Broth (TSB) containing skim milk and incubated at $28^{\circ} \mathrm{C}$ for 48 hours. The culture was then centrifuged at 5,000 rpm for $15 \mathrm{~min}$. at $4^{\circ} \mathrm{C}$. The supernatant obtained was a crude enzyme extract ready to use in the proteolytic activity test.

Proteolytic activity is determined based on the method of Bergmeyer \& Grassi (1983) (Table 1). Casein was hydrolyzed by proteases into peptides and amino acids. The amino acids were separated from the remaining concentrate by the addition of trichloroacetic acid (TCA) or perchloric acid. The amino acids formed were dissolved in TCA, whereas the non-hydrolyzed protein was settled in the presence of TCA. The isolated amino acids were measured their absorbance at a $280 \mathrm{~nm}$ wavelength or colored first with a folin-ciocalteau reagent at a wavelength of $650 \mathrm{~nm}$. One unit of activity represents the amount of enzyme that can produce one micromole of tyrosine per minute (Bergmeyer \& Grassi, 1983).

The activity of the protease is calculated by the formula:

$$
\frac{U}{\mathrm{~mL}}=\left[\frac{\mathrm{ODs}-\mathrm{ODb}}{\mathrm{ODstd}-\mathrm{ODb}}\right] \mathrm{DF} \times \frac{1}{\mathrm{~T}}
$$

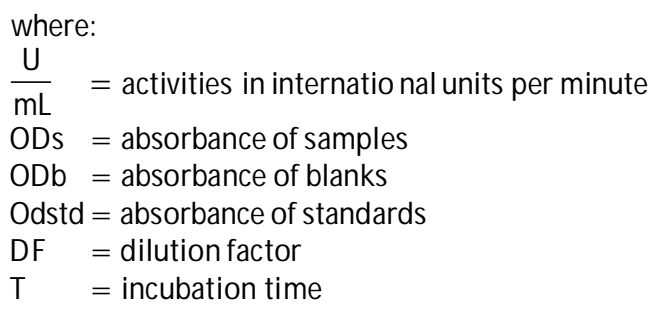

\section{Characterization of proteolytic bacteria in producing protease enzymes}

\section{Pathogenicity test}

The test was performed to determine the pathogenicity of proteolytic bacteria. All chosen isolates 
Table 1. Protease activity test

\begin{tabular}{|c|c|c|c|}
\hline Ingredients ${ }^{*}$ & Blank (mL) & Standard $(\mathrm{mL})$ & Sample $(\mathrm{mL})$ \\
\hline Buffer phosphate $(0.05 \mathrm{M}$; pH 8.0) & 1.00 & 1.00 & 1.00 \\
\hline Casein (20 mg/mL; pH 8.0) & 1.00 & 1.00 & 1.00 \\
\hline Enzyme on $\mathrm{CaCl}_{2}(2 \mathrm{mmol} / \mathrm{L})$ & - & - & 0.2 \\
\hline Tyrosine standard (5 mmol/L) & - & 0.20 & - \\
\hline Aquadest & 0.20 & - & - \\
\hline \multicolumn{4}{|l|}{ Incubated at $37^{\circ} \mathrm{C}$ for 10 minute } \\
\hline TCA $(0.1 \mathrm{M})$ & 2.00 & 2.00 & 2.00 \\
\hline Aquadest & - & - & 0.20 \\
\hline Enzymeon $\mathrm{CaCl}_{2}(2 \mathrm{mmol} / \mathrm{L})$ & 0.20 & 0.20 & - \\
\hline \multicolumn{4}{|l|}{$\begin{array}{l}\text { Incubated at } 37^{\circ} \mathrm{C} \text { for } 10 \text { minute, } \\
\text { then centrifuge at } 3,500 \mathrm{rpm} \text { for } 10 \text { minute }\end{array}$} \\
\hline Filtrat & 1.50 & 1.50 & 1.50 \\
\hline $\mathrm{Na}_{2} \mathrm{CO}_{3}(0.4 \mathrm{M})$ & 5.00 & 5.00 & 5.00 \\
\hline Folin ciocalteau & 1.00 & 1.00 & 1.00 \\
\hline
\end{tabular}

(RGL1.1, PL1.1, and PL2.1) were cultured for 24 hours at $28^{\circ} \mathrm{C}$. Each isolate, with a concentration of $10^{8} \mathrm{cfu} /$ $\mathrm{mL}$ and at a dose of $1 \mathrm{~mL}$, were then injected intramuscularly and intraperitoneally into the body of five healthy tilapia measuring an average weight of $10 \mathrm{~g}$. Another group of healthy tilapia (five individuals) was injected with phosphate buffer solution of $\mathrm{pH} 7$ with a dose of $1 \mathrm{~mL}$ as a control. Fish mortality, sickness, and abnormal activity were observed for two weeks. Each fish group used in the pathogenicity test was kept separately in two $60 \mathrm{~cm} \times 50 \mathrm{~cm} \times 40 \mathrm{~cm}$ aquarium.

\section{Determination of growth curve of proteolytic bacteria and optimum protease production time}

Pure rejuvenated isolates were cultivated in a fermented/production medium to study the protease activity. This process began with the production of inoculum then followed by the fermentation process (enzyme production). The inoculum, which has been incubated for $18-24$ hours at $30^{\circ} \mathrm{C}$, was taken as much as $10 \%$ to be inoculated into $100 \mathrm{~mL}$ of production medium. In every six hours, a sampling was performed to measure bacterial growth known as the optical density (OD) measurement at $650 \mathrm{~nm}$ wavelength. The measurement of protease enzyme activity used enzymatic method (Bergmeyer \& Grassi, 1983).

\section{Determination of optimum temperature and $\mathrm{pH}$ for proteolytic activity}

The optimum temperature and $\mathrm{pH}$ for proteolytic activity were determined as follow: the bacteria were cultured in a solution containing skim milk broth then incubated for 48 hours at temperature ranges of $30^{\circ} \mathrm{C}$, $40^{\circ} \mathrm{C}, 50^{\circ} \mathrm{C}$, and $60^{\circ} \mathrm{C}$ and at $\mathrm{pH}$ ranges of $5,6,7$, and 8. Afterward, the bacteria were tested for their proteolytic activity at the temperature and $\mathrm{pH}$ ranges until the optimum proteolytic activity of certain temperatures and $\mathrm{pH}$ were observed.

\section{Identification of Selected Proteolytic Bacteria}

The final stage of this study was the identification of the selected isolates through a series of morphological, biochemical, and molecular tests. The isolates were morphologically characterized their gram staining response, spore, and motility. The biochemical tests consisted of catalase, peptone, and gelatin. Molecular identification was conducted through bacterial DNA isolation performed using the PCR method (Packeiser et al., 2013). Cells from a single colony on a solid surface media were taken using sterile toothpicks and suspended into $50 \mu \mathrm{L}$ of nuclease-free water. Cell lysis was performed with a vortex suspension for 10 seconds and incubated at $98^{\circ} \mathrm{C}$ for five minutes. The lysate was further spun down to separate the supernatant from the cell debris. The supernatant was taken and used as a DNA template in PCR amplification.

The amplification of 16S rDNA fragments was performed using GoTaq (Promega) with primers 27F (5'AGAGTTTGATCCTGGCTCAG-3') and 1492R (5'GGTTACCTTGTTACGACTT-3') (Zhang et al., 2009; Palaniappan et al., 2010). The purification of PCR products was performed following the PEG precipitation method (Hiraishi et al., 1995) and continued with se- 
quencing cycles. The results of the sequencing cycles were regrouped using the ethanol purification method. The order of nitrogen bases was analyzed using an automated DNA sequencer (ABI PRISM 3130 Genetic Analyzer) (Applied Biosystems). The sequenced data were then processed with the Bioedit program. The homology of $16 \mathrm{~S}$ rDNA sequence was searched in Eztaxon servers online database (Kim et al., 2012).

\section{RESULTS AND DISCUSSION}

\section{Exploration and Isolation of Proteolytic Bacteria}

Protease-producing bacteria were selected and isolated from hot spring, crater, and mangrove sediments as well as shrimp head. The bacteria isolated from various growth substrates are presented in Table 2.

\section{Selection and Characterization of Protease- Producing Bacteria}

The results revealed that only 18 isolates of bacteria had proteolytic activity characterized by the formation of clear zones on agar media (Table 1). Nine isolates that had the highest proteolytic index were selected. The isolate that had the highest proteolytic index was obtained from Parung hot water sludge coded as PL1.2 (Table 3). Six of nine bacteria isolates with the highest proteolytic index had high protease activity of which, the highest activity was produced by bacterial isolate RGL1.1 (Table 4).

\section{Characterization of proteolytic bacteria in producing protease enzymes}

\section{Pathogenicity test}

Three isolates that had the highest enzyme activity were RGL1.1, PL1.1, and PL2.1. These isolates were subjected to the pathogenicity test to determine if they were a pathogen or not. The results showed that tilapia injected with PL1.1 and PL2.1 had died within 24 hours after injection. Seven fish injected with RGL1.1 had still alive during the pathogenicity tests while three other had died due to injuries caused by the injections. This indicates that RGL1.1 was not pathogenic to tilapia and can potentially be used as a candidate of protease producing bacteria to improve the quality of fish feedstuff.

\section{Growth curve of proteolytic bacteria and optimum protease production time}

Based on the growth curve, the lag phase of RGL1.1 isolate is from the initial time to the sixth hour of incubation time (Figure 1). The lag phase or adapta- tion phase is a condition in which nutritious microbial cells in previous cultures begin to adapt to their new environment (Morse \& M ietzner, 2013). The exponential phase of this isolate was quite long from the sixth hour until the thirty-sixth hour of incubation time. In the exponential phase, bacterial cells divide and cell metabolism progresses rapidly resulting in the increasing number of cells that keep going continuously until reaching a stationary phase (Sunaryanto, 2011). The stationary phase of RGL1.1. isolate began after the thirty-sixth hour marked by a decreased in bacterial growth until the forty-eighth hour. In this phase, the rate of bacterial growth was proportional to the rate of cell death and the accumulation of toxic metabolites in culture media. In this phase, the bacteria began to produce enzymes and other metabolites. This is due to the competition between cells over the increasingly depleted nutrients (Morse \& Mietzner, 2013).

Based on the protease production curve presented in Figure 2, it can be concluded that protease activity correlates positively to bacterial growth. The greater the number of cells, the greater the protease activity produced. The results showed that at the $36^{\text {th }}$ hour, the bacteria produced the highest protease activity, which was $0.089 \mathrm{U} / \mathrm{mL}$ and indicated the optimum incubation time.

\section{pH and Temperature Optimum}

The effect of $\mathrm{pH}$ on protease enzyme activity is presented in Figure 3. This study found that protease activity of bacteria isolated from hot spring sediment of Rengganis crater has an optimum condition at $\mathrm{pH}$ 6 considering that the optimum $\mathrm{pH}$ range of protease production varies according to its protease type. However, the optimum pH of protease in this study was still within the $\mathrm{pH}$ range between acidic and neutral. This is in line with Suhartono (1989), who reported that bacteria such as Bacillus subtilis could produce three kinds of protease enzyme namely acid, neutral, and alkaline proteases. At an optimum pH, the enzyme has an active side conformation that matches to the casein substrate leading to a maximum formation of a substrate-enzyme complex. At this point, the giver and receiver proton groups on the catalytic side of the enzyme are at the desired ionization level, which will generate the maximum product (Suhartono, 1989).

The catalytic activity of protease enzyme is also affected by temperature. Low temperature slows down the chemical reaction and higher temperature causes the reaction to occur more rapidly. The effect of temperature variations on RGL1.1 protease activity is presented in Figure 4. The protease activity of RGL1.1 
Table 2. Isolated proteolytic bacteria from various growth substrates coded according to the source locations

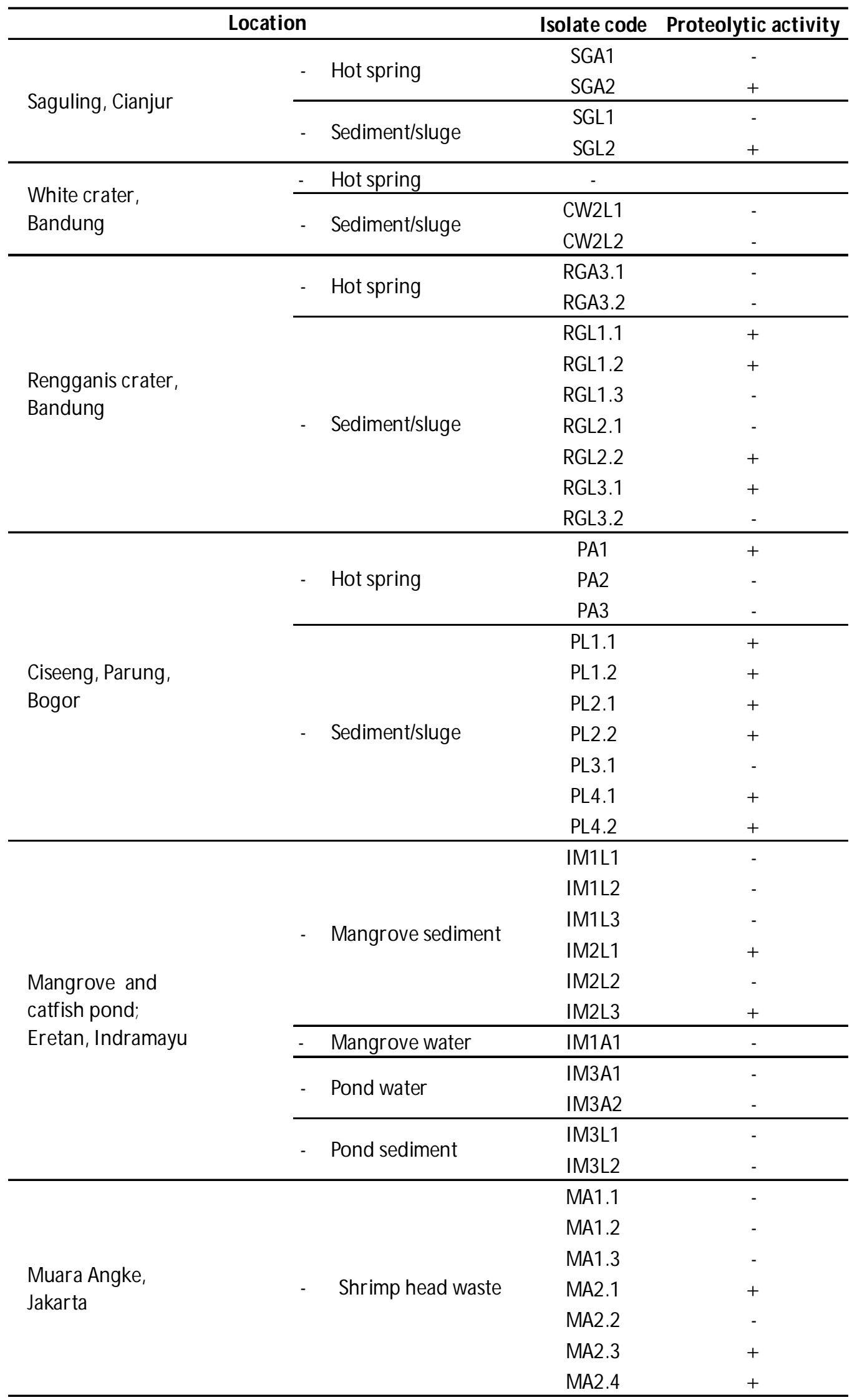


Table 3. Proteolytic index of bacteria isolated from different growth substrates

\begin{tabular}{cccc}
\hline Isolates code & Colony diameter $(\mathbf{m m})$ & Total zone $(\mathbf{m m})$ & Proteolytic index \\
\hline RGL.1.1 & 6 & 16 & 1.7 \\
RGL1.2 & 5 & 15 & 2 \\
PL.1.1 & 6 & 9 & 0.5 \\
PL1.2 & 4 & 17 & 3.3 \\
PL2.1 & 6 & 15 & 1.5 \\
PL2.2 & 5 & 10 & 1 \\
MA2.1 & 7 & 9 & 0.3 \\
IM2L3 & 3 & 9 & 2 \\
IM2.L1 & 2 & 7 & 2.5 \\
\hline
\end{tabular}

Table 4. Protease activity of isolates from various growth substrates measured quantitatively

\begin{tabular}{lc}
\hline \multicolumn{1}{c}{ Isolate code } & Proteolytic activity $(\mathbf{U} / \mathbf{m L})$ \\
\hline IM2L1.1 & $0.007 \pm 0.001$ \\
PL1.1 & $0.023 \pm 0.001$ \\
RGL1.1 & $0.100 \pm 0.006$ \\
PL2.1 & $0.015 \pm 0.004$ \\
PL2.2 & $0.0023 \pm 0.0004$ \\
RG1.2 & $0.004 \pm 0.003$ \\
\hline
\end{tabular}

Table 5. Pathogenicity test of proteolytic bacteria on tilapia (Oreochromis niloticus) for two weeks

\begin{tabular}{ccc}
\hline \multirow{2}{*}{$\begin{array}{c}\text { Isolate } \\
\text { code }\end{array}$} & \multicolumn{2}{c}{ Phatogenicity (two weeks) } \\
\cline { 2 - 3 } & Alive fish (ind.) & Dead fish (ind.) \\
\hline RGL1.1 & 7 & 3 \\
PL1.1 & 0 & $10^{*}$ \\
PL2.1 & 0 & $10^{*}$ \\
\hline
\end{tabular}

Notes: * Fish died after 24-hour post injection of proteolytic bacteria

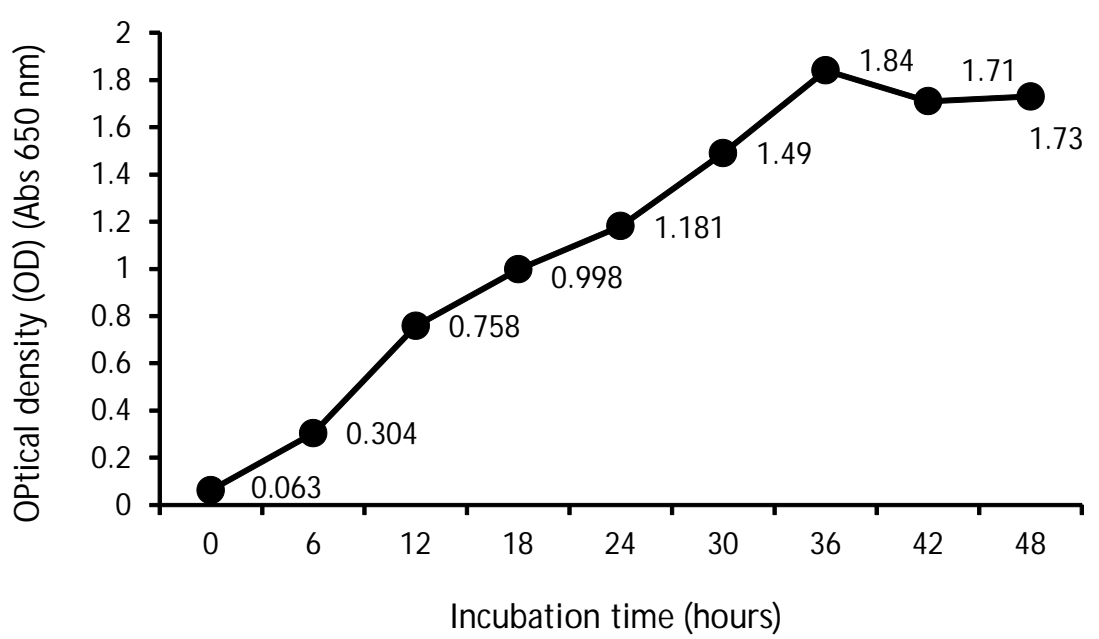

Figure 1. Growth curve of RGL1.1. 


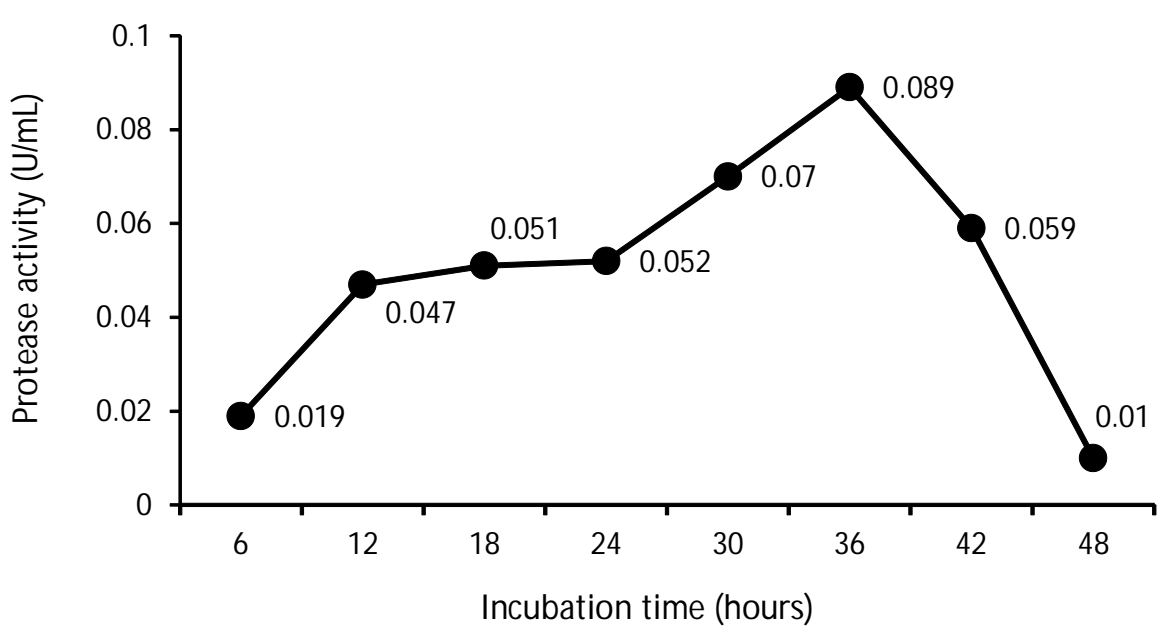

Figure 2. Proteolytic activity of RGL1.1.

isolate reached the optimum value at $50^{\circ} \mathrm{C}$. At this temperature, the interaction between the enzyme and the substrate is very effective to allow the easier formation of enzyme-substrate, so it will increase the product (Nelson \& Cox, 2005). The activity of protease enzyme of RGL1.1 isolate increased from $30^{\circ} \mathrm{C}$ to $50^{\circ} \mathrm{C}$ and decreased above $50^{\circ} \mathrm{C}$. After passing the optimum temperature, enzyme activity generally decreases because the enzyme begins to damage the active group. According to Muchtadi et al. (1992) in Fathimah \& Wardani (2014), enzymes have chemical bonds in the form of hydrogen, ionic/van der Waals bonds, and hydrophobic interactions that under normal circumstances maintain the structure of the enzyme. At high temperatures, this bond will break so that enzyme's proteins will denature causing the enzyme's active side to change conformation and reduce its catalytic activity. In addition, Montgomery (1993) in Fathimah \& Wardani (2014) argues that at high temperatures, important bonding forces are damaged by the increasing thermal vibrations of atoms thus destroying the three-dimensional structure of the enzyme. Similarly, the substrate may undergo a conformational change where its reactive group will be inhibited when entering the active site of the enzyme.

\section{Identification of Selected Proteolytic Bacteria}

The biochemical and morphological characterization of RGL1.1 is presented in Table 6. Based on the microscopic observations, the RGL1.1 isolate had a rod-shaped form, lined up into long chains, and was a Gram-positive type of bacteria (Figure 5). The bacteria gave a positive result in the catalase test, which

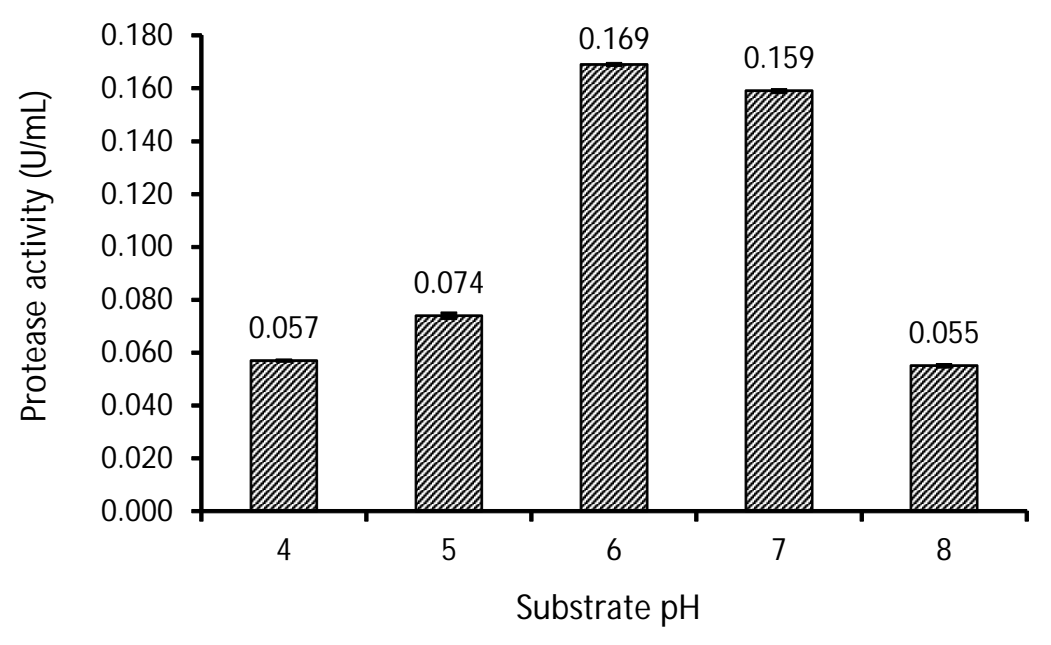

Figure 3. Protease activity $(\mathrm{U} / \mathrm{mL})$ of RGL1.1 isolate incubated at different $\mathrm{pH}$ levels. 


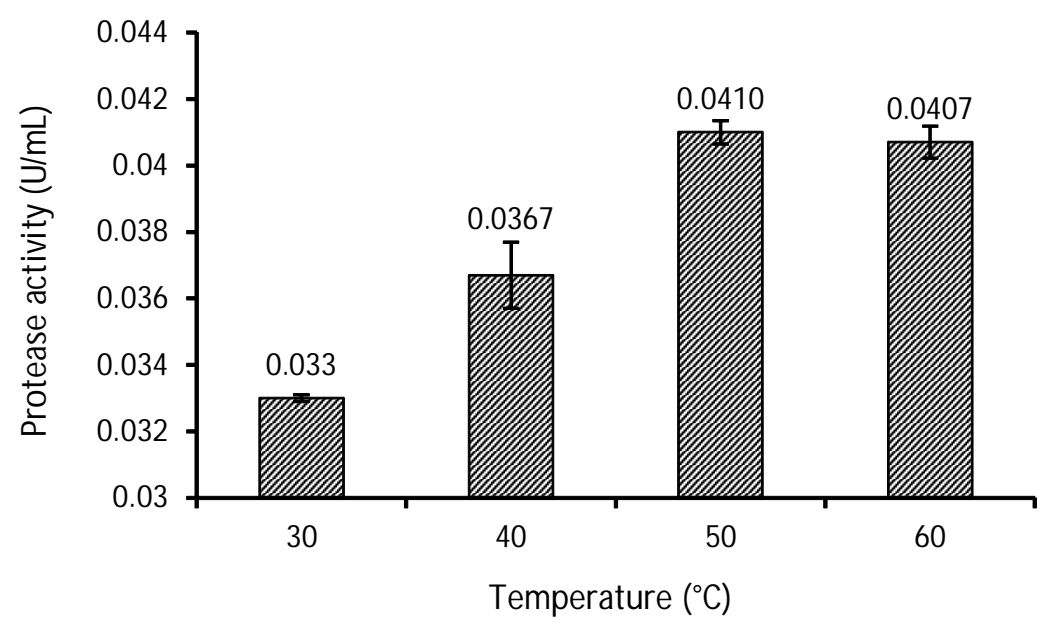

Figure 4. Protease activity $(\mathrm{U} / \mathrm{mL})$ of RGL1.1 isolate incubated at different temperatures.

showed that RGL1.1 isolate was able to live in aerobic conditions. Aerobic bacteria use catalase enzymes to detoxify hydrogen peroxide and superoxide radicals which are toxic by-products of aerobic metabolism (Martins et al., 2011). These bacteria also gave a positive result in oxidase enzymes test that indicates the bacterium has cytochrome oxidase which is a characteristic of aerobic organism (Trivedi et al., 2010).

In addition, RGL1.1 isolates were non-motile or immobilized characterized by the absence of flagella in the bacterial body. The bacteria also gave a positive result in gelatin test in which RGL1.1 isolate was able to hydrolyze gelatin and casein which are parts of protein.

The PCR results of RGL1.1 isolate were sequenced and analyzed using the EzTaxon server. The results showed that RGL-1.1 isolate had $99.93 \%$ similarities with Bacillus cereus (Table 7). Bacillus cereus is a rodshaped bacterium, a Gram-positive, motile, and en- dospore bacteria (Hema \& Shiny, 2012). This bacterium is potential to be used as a probiotic (de Souza et al., 2012) and can produce important enzymes such as proteases (M aal et al., 2009).

Protease is one type of hydrolase class enzyme that serves to break down proteins into simpler molecules, such as short oligo-peptides or amino acids by hydrolysis reactions in peptide bonds (Watanabe \& Hayano, 1994). This enzyme is needed by all living things because it is essential in the process of protein metabolism and plays a role in helping protein digestion in food (Polaina $\&$ MacCabe, 2007). This study showed that RG1.1 isolates could potentially be used as protease-producing bacteria. This was indicated by its high protein activity and was not pathogenic to tilapia. The protease enzyme produced by RG1.1 bacteria can be used as a supplement in the feed (enzyme or probiotic) or to ferment certain fish feed raw materials. Several studies on the use of proteases have been done to improve

Table 6. Morphological and biochemical properties of RGL1.1 bacteria

\begin{tabular}{lc}
\hline \multicolumn{1}{c}{ Type of test } & RGL1.1 isolate characteristics \\
\hline Gram & Positive \\
Colony shape & Milky white, rounded jagged with core \\
Cell shape & Rod shape \\
Catalase & + \\
Oxidase & + \\
Motility & Motile \\
Gelatin & + \\
Peptonization & + \\
\hline
\end{tabular}




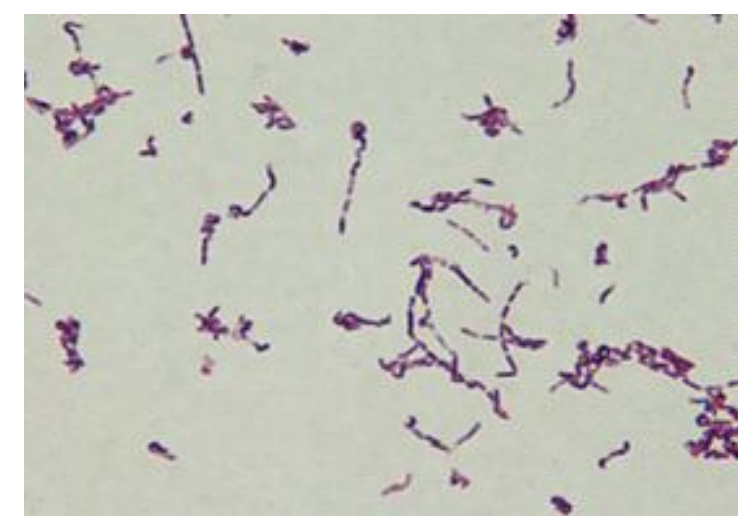

Figure 5. RGL1.1 isolate morphology.

the quality of feed and fish digestibility. For example, Drew et al. (2005) reported that proteases were able to improve nutrient and feed conversion of coextruded canola : peas feed than flax : peas feed. The same result was reported by Dalsgaard et al. (2012) where proteases were capable of improving nutrient digestibility from the soybean-based feed. According to Kemigabo et al. (2017), the addition of protease to catfish feed could increase the digestibility of the feed and an efficient protease utilization in feed could be reached if the feed contained $50 \% 55 \%$ of protein. Similarly, Irawati et al. (2015) and Ananda et al. (2015) reported that the addition of papain (protease) in artificial feeds had a significant effect on the relative growth, protein efficiency ratio, the feed efficiency of tilapia (Orerochromis niloticus) and catfish (Pangasius hypopthalmus). Besides as a supplement, protease can also be used to improve the quality of raw materials of fish feed. Mulia et al. (2014) reported that the fermentation of tofu waste with Aspergillus niger as proteolytic microbes could increase the levels of crude protein in the material. The use of an inoculum of $2.5 \mathrm{~mL} / 50 \mathrm{~g}$ of tofu wastes was able to increase the crude protein content of the tofu from $14.93 \%$ to
$27 \%$ Samaddar \& Kaviraj (2015) reported that the use of Lactobacillus acidophillus bacteria was an appropriate fermentation technique to improve the quality of animal blood for fish feed ingredient. The fermentation results showed an excellent protein quality containing several essential amino acids such as arginine, leucine, lysine, phenylalanine, threonin, and valine. The use of proteolytic bacteria (Bacillus subtilis) through fermentation can also improve the quality of poultry feather flour. Inoculum use of $10 \mathrm{~mL} / 2 \mathrm{~g}$ of chicken feather flour may increase the crude protein content of this flour from $73.56 \%$ to $80.59 \%$ (Mulia et al., 2016). The utilization of protease-treated blood gave a positive effect on the digestibility and growth of the fish. For example, Palinggi et al. (2013) reported that tiger grouper fed with a diet containing blood meal after treated with protease were not significantly different in weight gain, specific growth rate, protein retention, and feed efficiency with fish fed with a non blood meal. This suggests that the use of blood meal with protease did not have a negative effect on the growth performance of tiger grouper. Based on these reasons, RG1.1 isolate has a great opportunity to be developed as a protease producer

Table 7. Closed bacteria identity based on EzTaxon server analysis

\begin{tabular}{llll}
\hline $\begin{array}{c}\text { Sample } \\
\text { code }\end{array}$ & $\begin{array}{c}\text { Sequence } \\
\text { code }\end{array}$ & \multicolumn{1}{c}{$\begin{array}{c}\text { Closed bacteria identityfrom homology } \\
\text { result of EzTaxonserver } \\
\text { [www.ezbiocloud.net/eztaxon/results] }\end{array}$} \\
\hline \multirow{3}{*}{ RG1.1 $>$ contig_RG1.1 } & Bacillus cereus ATCC 14579(T) & \\
& Accesion no. & $:$ & AE016877 \\
& & Similarity & $99.93 \%$ \\
& & Length of alignment & $1,512 \mathrm{bp}$ \\
& Total nucleotide compared & $:$ & $1,343 \mathrm{bp}$ \\
& Different nucleotide & $:$ & 1 \\
& Completeness & $:$ & $100 \%$ \\
\hline
\end{tabular}


that can be utilized to improve the quality of fish feed and support better fish growth.

\section{CONCLUSION}

Based on the result of this research, it can be concluded that RGL1.1 isolate can potentially be utilized as protease producing bacteria. This isolate has been identified as a type of Gram-positive bacteria with rod shape that have $99.93 \%$ similarities with Bacillus cereus.

\section{ACKNOWLEDGEMENTS}

The authors offer a sincere gratitude to the Center for Research of Freshwater Aquaculture and Fisheries Extension Bogor for funding and facilitating this research. Special thanks to Dr. Ani Widiyati who provided help and advice during the research and writing phases of this paper. The authors thank Mr. Mikdarullah for his help in carrying out this research.

\section{REFERENCES}

Ananda, T., Rachmawati, D., \& Samidjan, I. (2015). Effect of papain on artificial feed on catfish growth (Pangasius hypopthalmus). Journal of Aquaculture Management and Technology, 4(1), 47-53.

Badriyah, B.I. \& Ardyati, T. (2013). Detection of proteolytic activity of bacterial isolates from tofu residue on rice bran. Journal of Biotropical, 1(3), 109-113.

Bergmeyer, H.U. \& Grassi, M. (1983). Methods of enzymatic analysis, volume 2 (p. 1007-1009). Weinheim: VerlagChemie.

Morse, S.A. \& Mietzner, T.A. (2013). Fundamental of microbiology. In Brooks, G.F., Carroll, K.C., Butel, J.S., Morse, S.A., \& M ietzner, T.A. Jawetz, M elnick, $\&$ Adelberg's M edical Microbiology. 26th ed. (p. 57). California: Lange Medical Publication.

Dalsgaard, J., Verlhac, V., Hjermitslev, N.H., Ekmann K.S., Fischer, M., Klausen, M., \& Pedersen, P.B. (2012). Effects of exogenous enzymes on apparent nutrient digestibility in rainbow trout (Oncorhynchus mykiss) fed diets with high inclusion of plant-based protein. Animal Feed Science and Technology, 171, 181-191.

de Souza, D.M., Martins, G.B., Piedras, S.R.N., Pouey, J.V.O.F., Robaldo, R.B., \& Leivas, F.P. (2012). Probiotic actions of Bacillus cereus var. toyoi and Saccharomyces boulardii in silver catfish (Rhamdia quelen) Iarvae culture. Revista Brasileira deZootecnia, (41)3, 815-819.

Drew, M.D., Racz, V.J., Gauthier, R., \&Thiessen, D.L. (2005). Effect of adding protease to coextruded flax: pea or canola: pea products on nutrient digestibility and growth performance of rainbow trout (Oncorhynchus mykiss). Animal Feed Scienceand Technology, 119, 117-128.

Fathimah, A.N. \& Wardani, A.K. (2014). Extraction and characterization of protease enzyme from moringa leaves (M oringa oliefera Lamk.). Journal of Agricultural Technology, 15(3), 191-200.

Firliani, W., Agustien, A., \& Febria, F.A. (2015). Characterization of thermophilic bacteria in producing neutral protease enzymes. Biology Journal of Andalas University, 4(1), 9-14.

Hema, T.A. \& Shiny, M. (2012). Production of protease enzyme from Bacillus clausii Sm3. IOSRJPBS, 1(4), 37-40.

Hiraishi, A., Kamagata, Y., \& Nakamura, K. (1995). Polymerase chain reaction amplification and restriction fragment length polymorphism analysis of $16 \mathrm{~S}$ rRNA genes from methanogens. Journal of Fermentation and Bioengineering, 79(5), 523-529.

Irawati, D., Rachmawati, D., \& Pinandoyo. (2015). Performance growth of black tilapia fish (Oreochromis niloticus Bleeker) through the addition of papain enzyme in artificial feed. Journal of Aquaculture Management and Technology, 4(1), 1-9.

Kemigabo, C., Kang'ombe, J., Masembe, C., Jere, L.W., \& Sikawa, D. (2017). Effects of protease enzyme supplementation on protein digestibility of legume and/or fish meal-based fish feeds. International Journal of Fisheries and Aquaculture, 9(7), 73-80.

Kim, O.S., Cho, Y.J., Lee, K., Yoon, S.H., Kim, M., Na, H., Park, S.C., Jeon, Y.S., Lee, J.H., Yi, H., Won, S., \& Chun, J. (2012). Introducing EzTaxon-e: a prokaryotic 16S rRNA gene sequence database with phylotypes that represent uncultured species. International Journal of System Evolution Microbiology, 62, 716-721.

Kurniawan, H.M. (2015). Isolated and extrinsic optimization of thermo-proteolytic bacteria isolated from hot spring of Semurup Kerinci, Jambi. Essay. Department of Biology, Faculty of Mathematics and Natural Sciences, Andalas University.

Maal, K.B., Emtiazi, G., \& Nahvi, I. (2009). Production of alkaline protease by Bacillus cereus and Bacillus polymixa in new industrial culture mediums and its immobilization. African Journal of Microbiology Research, 3(9), 491-497.

Marlina, T. (2014). Protein and fats in raw materials difficult feeding, really needed the role of lipase and protease enzymes. http:// www.livestockreview.com/protein-and-makerson-the-parts-the difficult-drivers-wedding-dis- 
abled-perimens-limase-and-protease/. [October 20, 2015].

Martins, P.F., Carvalho, G., Gratao, P.L., Dourado, M.N., Pileggi, M., Araujo, W.L., \& Azeveda, R.A. (2011). Effects of the herbicides acetochlor and metolachlor on antioxidant enzymes in soil bacteria. ProcessBiochemistry, 46, 1186-1195.

Mulia, D.S., Easy, M., Maryanto, H., \& Purbomartono, C. (2014). Fermented drugs know with Aspergillus niger to improve the quality of fish feed raw materials. Proceedings of the National Seminar on Research Results and Service of LPPM UM P 2014.

Mulia, D.S., Yuliningsih, R.T., Maryanto, H., \& Purbomartono, C. (2016). Utilization of chicken feather waste into fish feed material with Bacillus subtilis fermentation. Human and Environmental Journal, 23(1), 49-57.

Nelson, D. \& Cox, M. (2005). Lehninger principles of biochemistry. (p. 1216). 4th Ed. New York: W.H. Freeman and Company.

Packeiser, H., Lim, C., Balagurunathan, B., Wu, J., \& Zhao, H. (2013). An extremely simple and effective colony PCR procedure for bacteria, yeasts, and microalgae. Applied Biochemical Biotechnology, 169, 695-700.

Palaniappan, P., Chauhan, P.S., Saravanan, V.S., Anandham, R., \& Sa, T. (2010). Isolation and characterization of plant growth promoting endo phytic bacterial isolates from root nodule of Lespedeza sp. Biological Fertilizer Soils, 46, 807-816.

Palinggi, N.N., Paada, M.Y., Usman, \& Rachmansyah. (2013). Effect of blood meal flour result of enzymatic roses and fermentation in feeding to tiger grouper fish. Journal Aquaculture Research, 8(3), 403-415.
Polaina, J. \& MacCabe, A.P. (2007). Industrial enzymes; structure, function, and applications, (174 pp). Dordrecht: Springer.

Rahman, A. \& Indarto, C. (2013). Activity of solid waste microorganisms of tofu processing. National Seminar on Initiating the Resurrection of Local Commodities of Agricultural and Marine Commodities, ( $p$. 893-901). Madura, Indonesia: Faculty of Agriculture, Trunojoyo Madura University.

Samaddar, A. \& Kaviraj, A. (2015). Application of fermentation technology to use slaughterhouse blood as a potential protein supplement in fish feed. Jordan Journal of Biological Sciences, 8(1), 2330.

Suhartono, M. (1989). Enzymes and biotechnology, (p. 172-220). Bogor: Bogor Agricultural Institute Press.

Sunaryanto, R. (2011). Isolation, purification, identification, and optimization of antibiotic fermentation medium produced by marine actinomycetes. Master Thesis. Graduate School of Bogor Agricultural University.

Trivedi, P.C., Pandey, S., \& Bhadauria, S. (2010). Text book of microbiology, (p. 71-103). New Delhi: Aaviskhar Pub.

Watanabe, K. \& Hayano, K. (1994). Estimate of the source of soil protease in upland fields. Biology and Fertilizer Soils, 18, 341-346.

Zhang, W., Zhiyong, L., Miao, X., \& Zhang, F. (2009). The screening of antimicrobial bacteria with diverse novel nonribosomal peptide synthase (NRPS) genes from South China Sea sponges. Marine Biotechnology, 11, 346-35. 